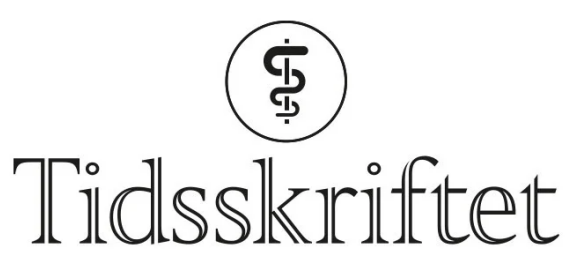

DEN NORSKE LEGEFORENING

\title{
Brukbart om demensomsorg
}

\author{
ANMELDELSER
}

ANNE RITA ØKSENGÅR

Forskningsleder, Nasjonalforeningen for folkehelsen

Anne Marie Mork Rokstad, Kari Lislerud Smebye

Personer med demens

Møte og samhandling. 2. utg. 374 s, tab, ill. Oslo: Cappelen Damm Akademisk, 2021, Pris NOK 498

ISBN 978-82-02-59107-6

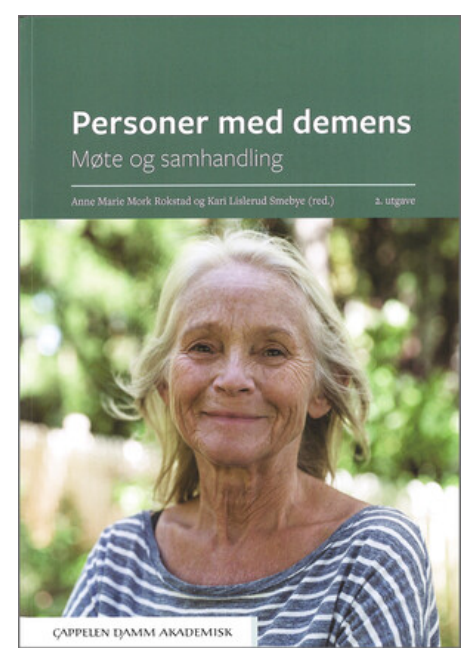

Demensplan 2025 vektlegger kompetanseheving i demensomsorgen og at all demensomsorg skal utføres i henhold til etikk, lovverk og nasjonale retningslinjer. Denne boken er et brukbart verktøy for å oppnå dette. Boken, som er like relevant for helsefagstudenter som for helsepersonell som jobber i omsorgssektoren, er en nyttig kunnskapsbasert fagbok. Den gir et viktig bidrag til kompetanseheving for å kunne gi ethvert menneske med demens best mulig kunnskapsbasert omsorg.

De ansvarlige har fått med seg medforfattere med lang erfaring innen sine fagfelt, hvilket gir boken et godt kvalitetsstempel. Det gis relevante praktiske eksempler på hvordan individuell personsentrert tilnærming er best for personer med demens. Temaer som utredning og diagnostikk, kommunikasjon, utfordrende atferd, miljøbehandling, 
selvbestemmelse, seksualitet, bruk av tvang, lindrende behandling og samarbeid med pårørende blir grundig diskutert. Demens hos yngre personer og hos personer med utviklingshemning er beskrevet godt i egne kapitler. I hvert kapittel har man vektlagt etisk, juridisk og faglig refleksjon i tråd med føringene i Demensplan 2025. Denne reviderte utgaven av boken er i så måte mer utfyllende enn tidligere utgaver.

Forfatterne beskriver begripelig hvordan det er å leve med ulike former for demens gjennom hele demensforløpet. Særlig er pasienteksemplene troverdige og gjør det hele levende og virkelighetsnært på en verdig måte. Erfaringsbasert kunnskap fortalt av personer med demens har kommet fint på plass. Dette er også i tråd med Demensplan 2025. «Man slutter ikke å være seg selv, selv om man får en demensdiagnose» er et utsagn fra en person med demens som tydeliggjør viktigheten av individrettet omsorg tilpasset den enkelte i alle faser av et demensforløp. Leserne får også beskrevet hvordan man kan samhandle med pårørende, hvilket er vesentlig for god demensomsorg.

Dette er likevel en typisk fagbok med faktarammer som inneholder viktig informasjon, til hjelp for å drive kvalitetssikret og kunnskapsbasert innenfor rammen av regelverk og nasjonale demensretningslinjer. Med dette grepet kan det være at boken først og fremst får lesere fra utdanningssektoren. Med en noe mer kortfattet tekst kunne den muligens fått en større leserskare blant dem som jobber daglig i praksisfeltet. Jeg håper likevel at mange oppdager bokens kvaliteter og at den får mange lesere som tar i bruk kunnskapen i sin hverdag som demensomsorgsarbeider.

Publisert: 28. februar 2022. Tidsskr Nor Legeforen. DOI: 10.4045/tidsskr.21.0838

(C) Tidsskrift for Den norske legeforening 2023. Lastet ned fra tidsskriftet.no 26. april 2023. 